\title{
Remote Sensing and GIS Based Potential Landslide Hazard Zonation in Ambo Woreda: Central Ethiopia
}

\author{
Mesfin Mengistu ${ }^{1} \quad$ Abebe Senamaw ${ }^{2}$ \\ 1. Department of Disaster Risk Management and Sustainable Development, Ambo University, Ambo Ethiopia \\ 2. Department of Disaster Risk Management and Sustainable Development, Ambo University
}

\begin{abstract}
:
Landslide hazard is becoming a serious problem in many parts of the world because of its frequent occurrence and related effects it is causing to human and properties. Areas of high altitude and steep slopes were susceptible to landslide hazards depending on their soil type, geology, land use/ land cover, proximity to road and streams, aspects, seismic level and ground water level variation. Even though there are problems related to landslide hazards in the region where Ambo woreda is located, there was significant landslide related scientific studies conducted in the area. The current study was aimed to prepare landslide hazard zonation map for Ambo Woreda based on landslide hazard causal factors including spatial rainfall distribution, local geology, slope, elevation, aspect, soil type, LULC, distance from stream and land slide inventory data based on Geographical Information System and remote sensing techniques. As a result 921 polygons covered an area of $32.9 \mathrm{~km}^{2}(3.43 \%)$ of the total study area was found with past landslide hazards. Past landslide hazard areas were studied to investigate the contribution of each landslide causing factors and to map the potential landslide hazard zones of Ambo woreda. Consequently the study area was categorized in to four levels of Potential Landslide Hazard Zones termed as very high, high, moderate, low and very low. The total area of about $959.7 \mathrm{~km}^{2}$, was classified as $14.7 \%, 53.28 \%, 23.43 \%, 4.99 \%$ and $3.6 \%$ among the very high, high, moderate, low and very low potential landslide hazard zones respectively. The presence of very high and high potential landslide hazard levels in wider area of Ambo woreda can be used as a warning message for local planners and the community to urgently plan for the reduction of potential landslide disaster risk reduction using various practices such as intensive soil and water conservation works and enhancing landslide disaster preparedness activities.
\end{abstract}

Keywords: Landslide Hazard, Landslide hazard zonation, Potential landslide hazard

DOI: $10.7176 / \mathrm{JEES} / 10-2-03$

Publication date: February $29^{\text {th }} 2020$

\section{Introduction}

Landslides are natural hazards occurring in many parts of the world as a result of geological/geomorphologic processes (Mahler et al., 2012). Landslides can be initiated by numerous natural factors including heavy rainfall, snowmelt, and changes in ground water level, erosion, earthquakes, volcanic activity, and disturbance of natural slopes. Deforestation/ changing vegetation coverage of the landscapes and mining are among many other human caused activities lead to occurrence of landslide hazards (Mandler, 2017; Hamza and Raghuvanshi 2016; Raghuvanshi et al., 2015; Raghuvanshi et al., 2014; Nakamura et al., 2014; Reichenbach et al., 2014).

Geomorphological conditions such as elevation, slopes, aspects, soil infiltration capacity, surface excavations, and rainfall, complex fragile geology with increased manmade activities such as construction of roads on mountains, Land Use/ Land Cover (LULC) change and heavy rain are the major causing factors of past landslides in Ethiopia (Kifle, 2013; Karsli et al., 2008; Kifle et al., 2006 and Girma et al., 2015; Ayalew and Yamagishi, 2004).

Landslide hazards have the potential to cause loss of life and damage to man-made structures and other environmental elements (Gertsema and Highland, 2011). Landslide hazards occurred in different parts of the world during 2004 to 2016 resulted to death of 55,997 people as indicated in various sources. And few studies conducted in several parts of Ethiopia indicated landslides were caused disasters in in areas such as northern highlands (Dessie areas, Shale hill slopes, Tigray, Tekeze areas), Central highlands (Abay basin, Jema basin, West Shoa, Tarmaber and surroundings), Southern regions (Gofa, Gilgel Gibe II, Sodo-Shone area and Wondo Genet) and in several places of Ethiopian rift valley margins (Kifle 2013 and Abebe et al., 2010).

From 1993-1998 losses of 300 people, demolishing of 200 houses, damaging of $100 \mathrm{~km}$ road and devastating of more than 500 hectares of agricultural land were recorded at different parts of Ethiopia (Ayalew, 1999 and Kifle, 2013). From 1999 - 2008 more than 135 death of human, destruction of 1450 houses, displacement of 6,500 people, damaging of more than 2000 hectare of land and more than $100 \mathrm{~km}$ asphalt roads and damage of resources estimated to 1.5 million dollars were documented in Ayalew (1999) and Kifle, (2013).

Landslide hazard initiated by the torrential rains during the summer of 2018 caused 23 death and 15 injuries to people, death of more than 30 domestic animals, damaging of 12 homes and more than 6 hectares of land in southern region of Ethiopia. Similarly more than 30 people died in Addis Ababa city as a result of landfills sliding during 2017. According to Kifle (2013) land slide disasters in Ethiopia may exceed beyond what were reported 
because many of them were not reported unless they located around the economic routs and derived the communities for critical support from the government.

In Ambo woreda there was no considerable scientific studies conducted concerning the causal factors, distribution and consequences of landslide hazards. But Ambo woreda is characterized by high number of population and various resources exposed to Potential Landslide Hazard (PLSH) that will possibly cause significant injuries and damage of property unless precaution measures will be taken based on the results of scientific studies. The present study was aimed to prepare landslide hazard zonation map for Ambo Woreda based on landslide hazard causal factors including spatial rainfall distribution, local geology, slope, elevation, aspect, soil type, LULC, distance from stream and land slide inventory data.

\section{Methodology}

\subsection{Study Area}

The study was conducted in Ambo woreda found in West Shewa Zone part of Oromia regional state in central Ethiopia. The administrative center of this wereda is Ambo town (Figure 1). The geographical location of Ambo Wereda is found between $\left(8^{0} 47^{\prime}-9^{0} 21^{\prime}\right) \mathrm{N}$ and $\left(37^{0} 32^{\prime}-38^{0} 3^{\prime}\right) \mathrm{E}$ (Figure.1). Ambo wereda is located at a distance of $114 \mathrm{~km}$ from Addis Ababa the capital city of Ethiopia. According to Ethiopian Central Statistical Agency's (ECSA) census data of 2007, the population of Ambo Wereda was 202,655 (99,859 male and 102,796 female) (ECSA, 2010).

According to the data obtained from Ethiopian Metrological Agency (EMA), Ambo Wereda is characterized by mean annual average rainfall of $1036 \mathrm{~mm}$ while other nearby stations indicated the presence high rainfall reaches $1241 \mathrm{~mm}$ and its maximum and minimum temperature ranges from $10 \mathrm{o}^{\mathrm{C}}-28 \mathrm{o}^{\mathrm{C}}$ respectively. The altitude of the area varies from 1277 - 3225 meter above sea level and it has lowland, midland and highland agro climatic zones.

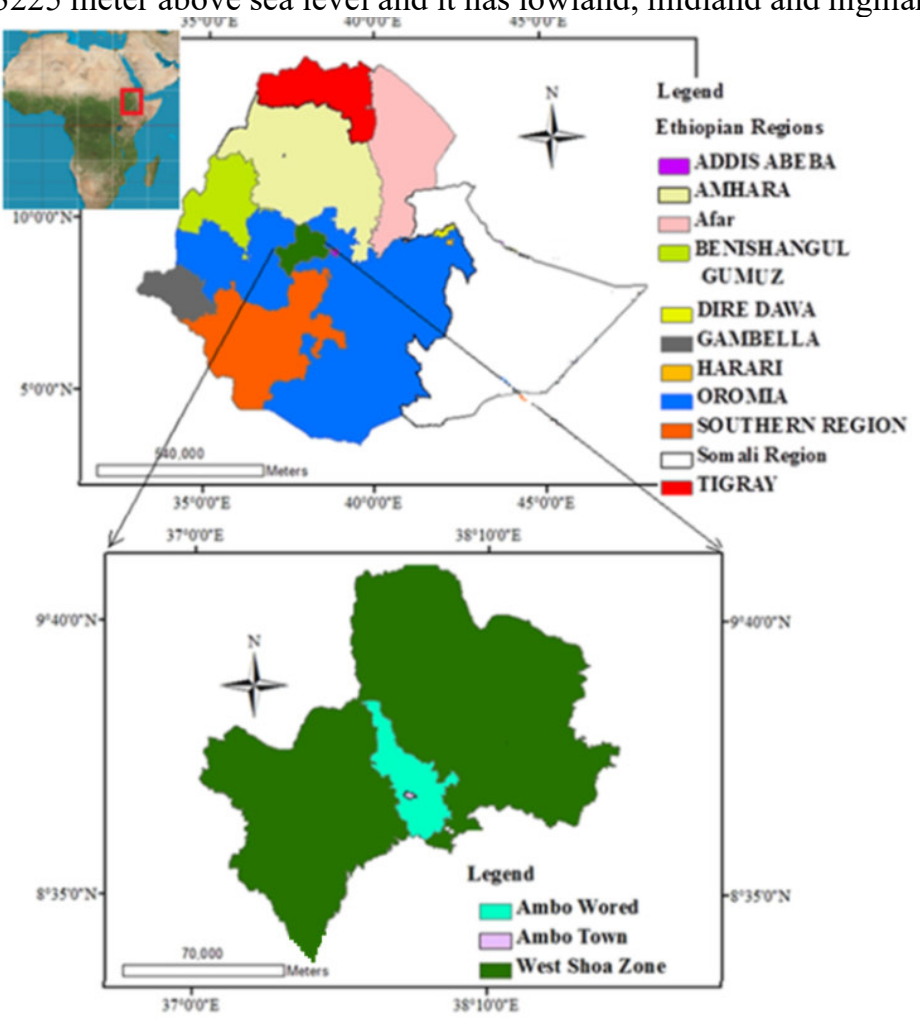

Figure 1 Location map of the study area

\subsection{Methods of data collection and Analyses}

The methodology followed for landslide hazard zonation of Ambo woreda using GIS and remote sensing techniques, divided into three phases namely: pre-fieldwork, fieldwork and post field work.

\subsubsection{Pre-fieldwork}

At this phase base map preparation, image downloading, geo referencing and projection, topographic map preparation and secondary data collection were carried out.

Elevation, slope, aspect, soil, geology, and distance from the stream, rainfall, elevation, slope, aspect and distance from the stream map layers were generated from DEM of resolution 90m downloaded from Advanced Space-borne Thermal Emission and Reflection Radiometer (ASTER). Rain fall data of 7 stations (table 1) were obtained from EMA. Inverse Distance Weighting (IDW) interpolation model was adopted to prepare the layer map 
of spatial rainfall distribution of the study area (figure 3H). GIS techniques were applied to prepare all the factor layer maps in Arc Map version 10.2. And all maps used in this study were geo-referenced based on GCS-WGS1984 and projected to the coordinate system of Universal Transverse Mercator (UTM) zone 37N (WGS, 37N).

\subsubsection{Field work}

Landslide inventory, ground control points collection was conducted for LULC, soil and geology. GPS instrument was used to collect and recorded locations of past landslides and information of LU/LC types, geological units and nature of soil in the study area were studied and notes were taken during the field work for verification and further analysis at office.

\subsubsection{Post field work}

Following the field study and literature review, landslide inventory mapping, LULC map preparation, soil map and geological map preparation and assembling and preparation of all raster maps and reclassification of landslide triggering data/factors, analyses of landslide factors in relation to landslide inventory results, factor weighting and potential landslide hazard zonation mapping were conducted. The soil map was prepared from FAO (1974) with minimum modifications based on field investigations. Geology of the study area was modified from existing Ethiopian geology map prepared by Geological survey of Ethiopia (GSE) during 1972 after field investigation. Landsat 8 OLI/TIR image of February 2018 downloaded from USGS was used to classify LU/LC of the study area based on supervised classification techniques.

\section{Result and Discussions}

\subsection{Landslide Hazard Inventory Mapping}

Landslide inventory map was prepared based on past landslide data collected from field and Google Earth Image (Figure 2 B) (GEI). Global Positioning System (GPS) instrument was used to collect and record locations of past landslides during field investigations (Figure 2 A). Mapping of landslide polygons were made by importing the data collected from field and GEI to Arc Map. A total of 921 polygons of past landslides covered $32.9 \mathrm{Km}^{2}(3.43 \%)$ of the total area of Ambo woreda were mapped (Figure 2 D). The resulted landslide inventory map was used to evaluate landslide triggering factors and potential landslide hazards.

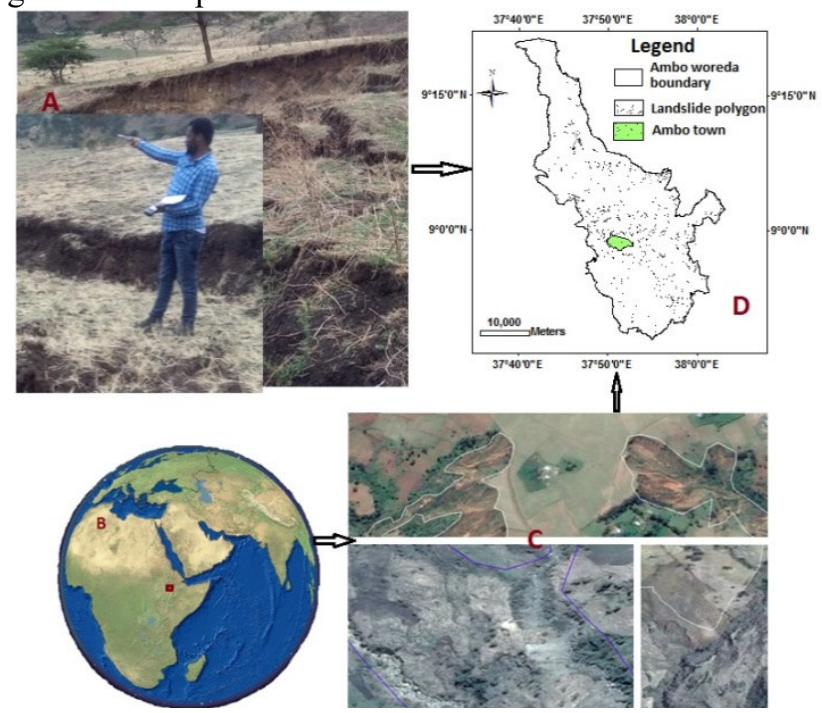

Figure 2 Landslide inventory map of Ambo woreda (D) prepared based on field investigation data (A) and Google Earth Image (B and C)

\subsection{Landslide Hazard Causing Factors Generating}

Eight landslide hazard triggering factors were identified for the present study following detail field investigation and literature reviews. The eight landslide triggering factors identified as a causal factors for PLSH analyses of Ambo woreda are listed as elevation, slope, aspect, soil, geology, and distance from the stream, rainfall and LULC. The factors were reclassified in to sub factors for further analysis (Table 2).

The reclassified landslide causing factors were weighted (table 3) using the Statistical Index (SI) model approach that was introduced by Van Westen (equation1). The SI model is a bivariate statistical analysis that has been widely used in many studies (Oztekin and Topal, 2005 and Pourghasemi, et.al, 2013). In the SI method, the weighted value for each categorical unit of the factor causing landslide hazard is expressed as the natural logarithm of the area of landslide hazard in any class divided by area of landslide hazard in the entire study area. This method is based on the distribution of landslide hazards across each class. Weighted factors overlay methods of GIS was used to determine the Landslide Hazard Index (LSHI) based on equation 2.The LSHI was used to zone the PLSH 
of Ambo woreda (Figure 4) after reclassification of LSHI based on natural breaks system of Arc Map (Table 4). The highest value of LSHI represent the highest degree of potential landslide hazard while the lowest value represent the lowest degree of landslide hazard.

Table 1

Average annual rainfall of 7 different stations

\begin{tabular}{|c|c|c|c|c|c|c|c|}
\hline \multirow[t]{2}{*}{ Station } & \multirow[t]{2}{*}{ Rainfall } & \multicolumn{2}{|c|}{ Geographic Coordinate } & \multirow[t]{2}{*}{ Station } & \multirow[t]{2}{*}{ Rainfall } & \multicolumn{2}{|c|}{ Geographic Coordinate } \\
\hline & & Easting & Northing & & & Easting & Northing \\
\hline Ambo & 1036 & 37.8700 & 8.9700 & Bako & 1237 & 37.0833 & 9.1167 \\
\hline Ginchi & 1135 & 38.1333 & 9.0167 & Busa & 1177 & 38.1382 & 8.7725 \\
\hline Jeldu & 1241 & 38.0833 & 9.2500 & Tulu- & 1109 & 38.2065 & 8.6545 \\
\hline Weliso & 1210 & 37.9833 & 8.5500 & Bolo & & & \\
\hline
\end{tabular}

Table 2

Reclassified Landslide hazard triggering factors

\begin{tabular}{|l|l|l|l|l|l|l|l|l|l|}
\hline $\begin{array}{l}\text { Landslide } \\
\text { triggering } \\
\text { factor }\end{array}$ & \multicolumn{6}{|l|}{ Landslide triggering factor class } \\
\hline Elevation(m) & $\begin{array}{l}1277- \\
1706\end{array}$ & $\begin{array}{l}1706- \\
2093\end{array}$ & $\begin{array}{l}2093- \\
2372\end{array}$ & $\begin{array}{l}2372- \\
2674\end{array}$ & $\begin{array}{l}2674- \\
3225\end{array}$ & & & & \\
\hline Slope & $0-5$ & $5-12$ & $12-30$ & $30-38$ & & & & & \\
\hline Aspect & Flat & North & Northeast & East & Southeast & $\begin{array}{l}\text { South } \\
\text { west }\end{array}$ & West & $\begin{array}{l}\text { North } \\
\text { west }\end{array}$ & North \\
\hline Soil & Cambisols & Leptosols & Luvisols & Nitosols & Vertisols & & & & \\
\hline Geology & Sandstone & Basaltic & lava flow & Limestone & Gypsum & & & & \\
\hline $\begin{array}{l}\text { Distance } \\
\text { from Stream }\end{array}$ & $0-50$ & $50-250$ & $250-1000$ & $>1000$ & & & & & \\
\hline $\begin{array}{l}\text { Rainfall(mm) } \\
1036-\end{array}$ & $\begin{array}{l}1077- \\
1118\end{array}$ & $\begin{array}{l}1118- \\
1159\end{array}$ & $\begin{array}{l}1159- \\
1200\end{array}$ & $\begin{array}{l}1200- \\
1241\end{array}$ & & & & \\
\hline $\begin{array}{l}\text { Land } \\
\text { use/Land } \\
\text { cover }\end{array}$ & Settlement & Rangeland & Shrub & Bare land & Forest & Agriculture & & & \\
\hline
\end{tabular}

$W i j=\ln \left(\frac{(N i j / M i j)}{(N / M)}\right) \ldots \ldots \ldots \ldots \ldots \ldots .$. Equation 1

Where:

- Wij is the weight of the $\mathrm{i}^{\text {th }}$ class of the $\mathrm{j}^{\text {th }}$ parameter

- $\quad \mathrm{Nij}$ is the area with landslide hazard in the $\mathrm{i}^{\text {th }}$ class of the $\mathrm{j}^{\text {th }}$ parameter

Mij is the area in the $\mathrm{i}^{\text {th }}$ class of the $\mathrm{j}^{\text {th }}$ parameter

- $\quad \mathrm{N}$ is the total area with landslide hazards

- $\mathrm{M}$ is the total area of Ambo woreda

$L S H I=\sum W i j$ Equation2 


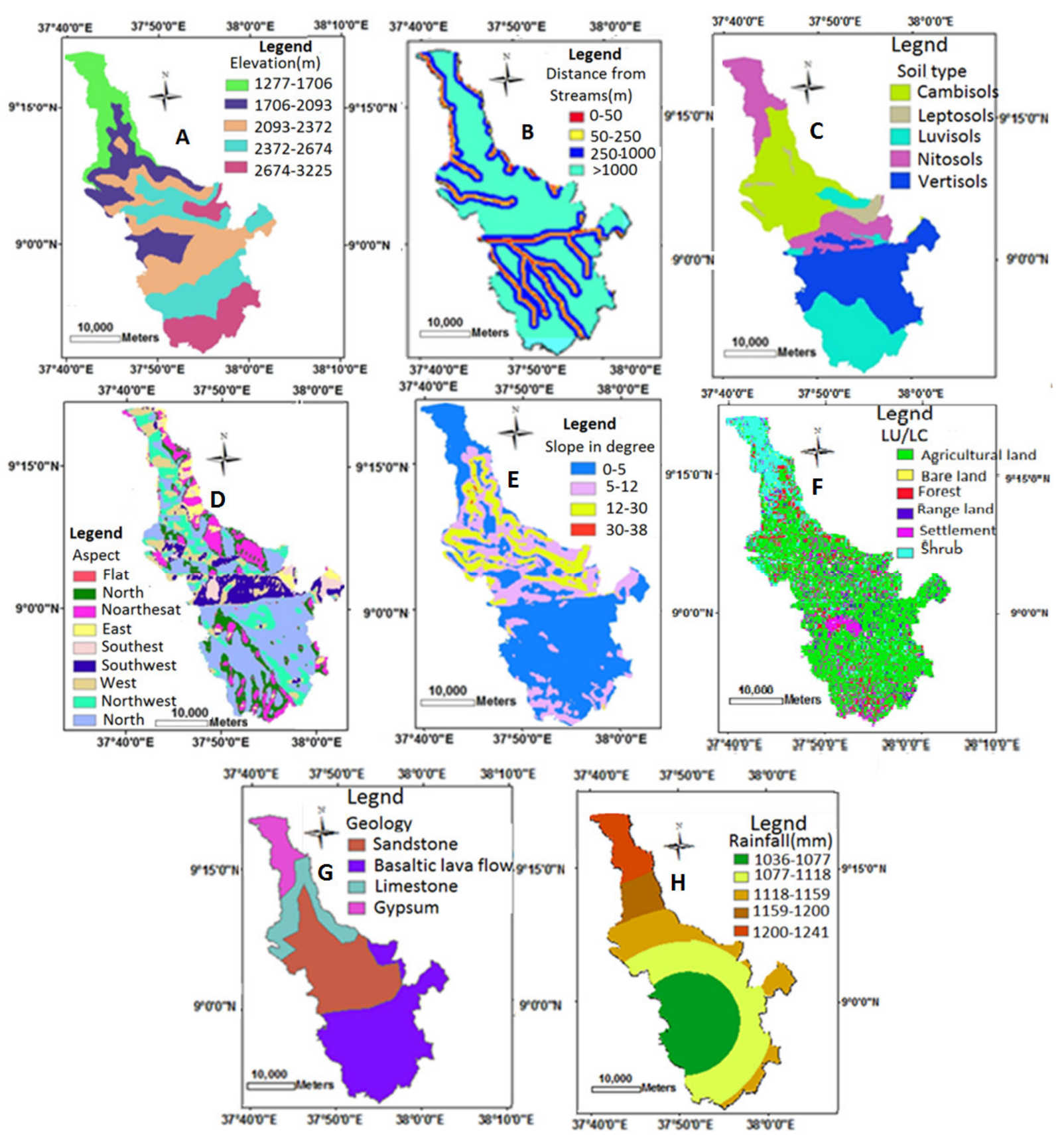

Figure 3 Elevation (A), distance from the stream (B), soil type (C) aspect (D), slope (E), LU/LC (F), geology (G) and rainfall $(\mathrm{H})$ maps of Ambo wored. 
Table 3

Landslide hazard causing factors reclassified and weight

\begin{tabular}{|c|c|c|c|c|c|c|c|c|c|}
\hline Factor & Factor class & $\mathrm{M}_{\mathrm{ij}}\left(\mathrm{Km}^{2}\right)$ & $\begin{array}{l}\mathrm{N}_{\mathrm{ij}} \\
\left(\mathrm{Km}^{2}\right)\end{array}$ & $\mathrm{W}_{\mathrm{ij}}$ & Factor & Factor class & $\mathrm{M}_{\mathrm{ij}}\left(\mathrm{Km}^{2}\right)$ & $\begin{array}{l}\mathrm{N}_{\mathrm{ij}} \\
\left(\mathrm{Km}^{2}\right)\end{array}$ & $\mathrm{W}_{\mathrm{ij}}$ \\
\hline \multirow[t]{7}{*}{ Elevation(m) } & $1277-1706$ & 130.1726 & 0.49 & -2.20 & \multirow[t]{6}{*}{ Geology } & Sandstone & 324.2051 & 11.1961 & 0.01 \\
\hline & 1706-2093 & 174.2715 & 8.55 & 0.36 & & $\begin{array}{r}\text { Basaltic } \\
\text { lava }\end{array}$ & 430.3664 & 8.1195 & $\begin{array}{l}- \\
0.60\end{array}$ \\
\hline & $2093-2372$ & 276.3632 & 13.74 & 0.37 & & Limestone & 123.1504 & 12.9241 & 1.12 \\
\hline & $2372-2674$ & 231.6777 & 6.62 & -0.18 & & Gypsum & 81.9383 & 0.6507 & - \\
\hline & & & & & & & & & 1.46 \\
\hline & \multirow{2}{*}{$\begin{array}{r}2674-3225 \\
\text { Total } \\
\end{array}$} & 147.1752 & 3.47 & \multirow[t]{3}{*}{-0.37} & & Total & 959.6602 & 32.8905 & \\
\hline & & 959.6602 & 32.8905 & & Distance & $0-50$ & 49.7319 & 2.3521 & 0.32 \\
\hline & & & & & from & & & & \\
\hline \multirow[t]{6}{*}{ Slope } & $0-5$ & 544.3440 & 15.9019 & -0.16 & \multirow[t]{5}{*}{ Stream } & $50-250$ & 77.6441 & 5.1383 & 0.66 \\
\hline & $5-12$ & 280.3595 & 12.8449 & 0.29 & & $250-1000$ & 252.7519 & 20.5174 & 0.86 \\
\hline & $12-30$ & 133.7756 & 4.1383 & -0.10 & & $>1000$ & 579.5323 & 4.8826 & - \\
\hline & & & & & & & & & 1.40 \\
\hline & $30-38$ & 1.1811 & 0.0054 & \multirow[t]{2}{*}{-2.01} & & Total & 959.6602 & 32.8905 & \\
\hline & Total & 959.6602 & 32.8905 & & \multirow{9}{*}{$\begin{array}{l}\text { Rainfall } \\
(\mathrm{mm})\end{array}$} & 1036-1077 & 285.4021 & 13.0350 & 0.29 \\
\hline \multirow[t]{13}{*}{ Aspect } & Flat & 5.3904 & 0.1364 & -0.30 & & $1077-1118$ & 335.0205 & 10.3621 & - \\
\hline & & & & & & & & & 0.10 \\
\hline & North & 100.4719 & 1.6045 & -0.76 & & $1118-1159$ & 186.0395 & 7.2399 & 0.13 \\
\hline & Northeast & 116.2372 & 2.5594 & -0.44 & & $1159-1200$ & 65.7216 & 1.8411 & - \\
\hline & & & & & & & & & 0.20 \\
\hline & East & 40.7757 & 1.6099 & 0.14 & & $1200-1241$ & 87.4765 & 0.4123 & - \\
\hline & & & & & & & & & 1.98 \\
\hline & Southeast & 35.7895 & 1.7174 & 0.34 & & Total & 959.6602 & 32.8905 & \\
\hline & Southwest & 91.3825 & 6.0465 & 0.66 & \multirow{8}{*}{$\begin{array}{l}\text { Land } \\
\text { use/Land } \\
\text { cover }\end{array}$} & Settlement & 102.2024 & 9.3839 & 0.99 \\
\hline & West & 92.4313 & 3.9136 & 0.21 & & Rangeland & 30.4550 & 6.5883 & 1.84 \\
\hline & Northwest & 122.1659 & 4.5297 & 0.08 & & Shrub & 150.9230 & 7.1602 & 0.33 \\
\hline & North & 355.0157 & 10.7732 & -0.12 & & Bare land & 2.4307 & 0.0878 & 0.05 \\
\hline & Total & 959.6602 & 32.8905 & & & Forest & 71.6279 & 3.9848 & 0.48 \\
\hline \multirow[t]{6}{*}{ Soil } & Cambisols & 171.1436 & 5.2624 & -0.11 & & Agriculture & 602.0213 & 5.6855 & \multirow{3}{*}{$\begin{array}{l}- \\
1.29\end{array}$} \\
\hline & Lentosols & 2493280 & 87473 & 002 & & Total & 9596602 & 328905 & \\
\hline & Luvisols & 206.2401 & 5.7017 & -0.21 & & & & & \\
\hline & Nitosols & 30.4307 & 1.4715 & 0.34 & & & & & \\
\hline & Vertisols & 302.5177 & 11.7075 & 0.12 & & & & & \\
\hline & Total & 959.6602 & 32.8905 & & & & & & \\
\hline
\end{tabular}

\subsection{Landslide Hazard Zonation}

After factor analyses was made using equation 2, LSHI value of between (-9.05) and 4.103 (Table 4) was found. Reclassification of the LSHI was made and resulted to very high, high, medium, low and very low potential landslide hazard zones. The percentage of each hazard zones were found as $14.70 \%, 53.30 \%, 23.40 \%, 5 \%$ and $3.6 \%$ for the very high, high, moderate, low and very low hazard levels respectively while the total area of Ambo woreda is $959.70 \mathrm{~km}^{2}$. The landslide hazard zonation map resulted from the methodology of this study (Figure 4) show that the northern parts of the mapped area is found in very low, low and moderate PLSH while high PLSH zones were found widly in the southern parts of the study area.About $53.30 \%$ of study areais covered by high PLSH is widly distributed throughout the study area except in the Northern and Southern tips of the study area. Very high PLSH zones were signficantly found in the central parts of the mapped are. 


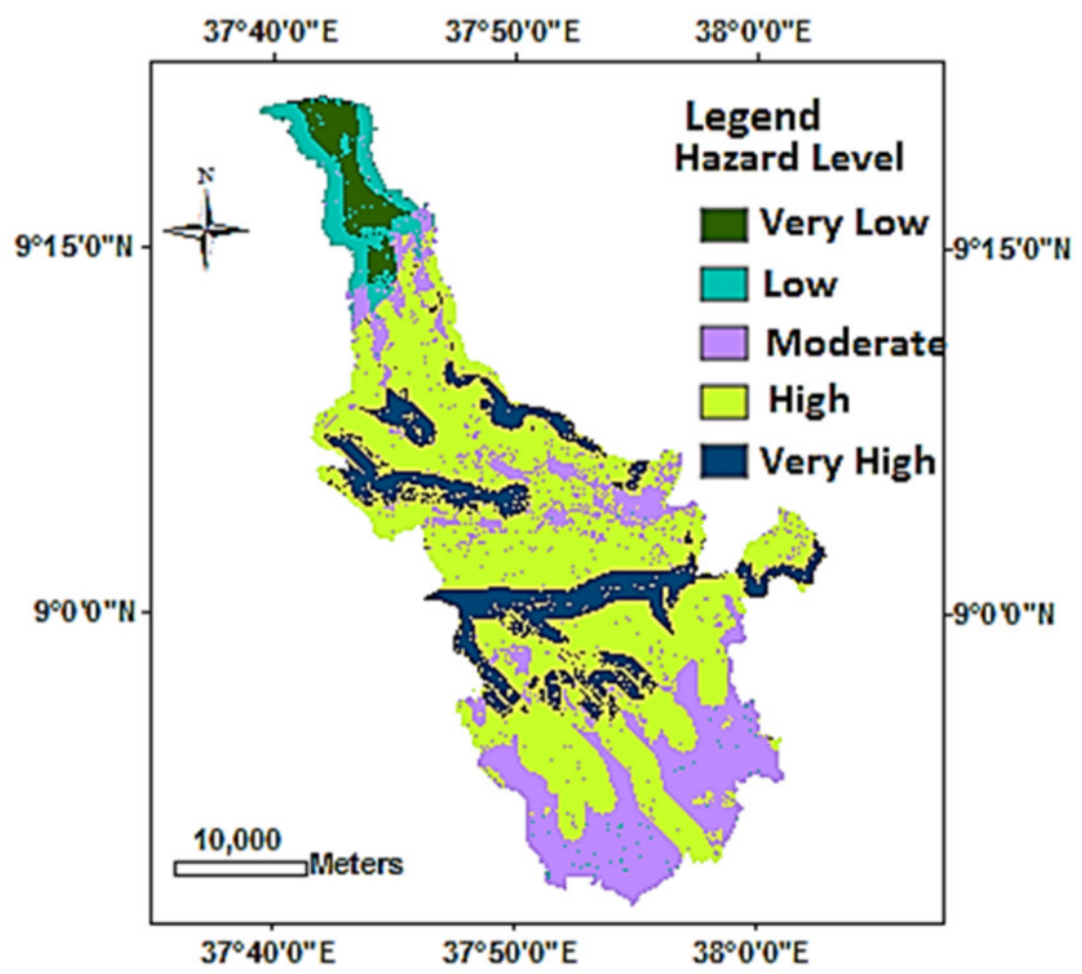

Figure 4 Landslide hazard zonation map of Ambo woreda

Table 4

Landslide Hazard zones and their area coverage

\begin{tabular}{llcl}
\hline LSHI & Hazard Zone & Area $\left(\mathrm{Km}^{2}\right)$ & \% of hazard zone \\
\hline$(-9.045185)-(-5.604078)$ & Very Low & 34.60 & 3.60 \\
$(-5.604078)-(-2.984728)$ & Low & 47.90 & 5.00 \\
$(-2.984728)-(-0.776256)$ & Moderate & 224.80 & 23.40 \\
$(-0.776256)-(0.969977)$ & High & 511.30 & 53.30 \\
$(0.969977)-(4.102926)$ & Very High & 141.10 & 14.70 \\
Total & & 959.70 & 100.00 \\
\hline
\end{tabular}

\section{Validation of Landslide Hazard Map}

The LSH map presented in this study was validated using past landslide inventory data and overlay analysis method. The overly analysis result indicated $66.66 \%$ of past landslide hazards occurred in high PLSH zone; $19 \%$ in very high PLSH zone, $13.83 \%$ in moderate PLSH zone; $0.27 \%$ in low PLSH zone and $0.25 \%$ in very low PLSH zone (Table 5). Thus, the landslide hazard zones map attained in the present study shows that there is concrete agreement between the past landslide hazards distribution and the present result of landslide hazards zonation map.

Table 5

Distribution of past landslide hazards in the PLSH zones

\begin{tabular}{lcl}
\hline Potential & Area of Past LSH in & \% of Past LSH in potential LSH zone \\
Landslide Hazard zone & Potential LSH zone $\left(\mathrm{km}^{2}\right)$ & \\
\hline Very Low & 0.08 & 0.25 \\
Low & 0.09 & 0.27 \\
Moderate & 4.55 & 13.83 \\
High & 21.92 & 66.66 \\
Very High & 6.25 & 19.00 \\
Total & 32.89 & 100.00 \\
\hline
\end{tabular}

\section{Conclusion and Recommendations}

The present study was focused on evaluating PLSH distribution of Ambo woreda based on field study and eight landslide hazard causal factors, elevation, slope, aspect, soil type, geology, rainfall, LU/LC and distance from the streams obtained from different sources such as field investigation, DEM and remote sensing and existing maps and finally processed using GIS techniques in ArcGIS software. 
Past landslide hazard inventory was made to understand the nature of landslide causal factors in areas of past landslide hazards to realize how they influenced the landslide causal factors in order to get an insight how they will contribute for the future PLSH and contributed in preparing the PLSH map of the study area.

GIS techniques were applied to prepare factor map of each landslide causal factors, to reclassify the factor maps and to overly the reclassified and weighted maps in order to obtain the final PLSH zonation map for the study area. Accordingly the study area is classified into five PLSH zones as very high, high, moderate, low and very low. The total area of the woreda under consideration was classified as $53.3 \%, 23.4 \%, 14.7 \%, 5 \%, 3.6 \%$ among high, moderate, high, low and very low PLSH zones. The very high and high PLSH zones share majority of the area which is $68 \%$. The existence of wider area coverage of in the study area indicates the need of urgent land use planning, close monitoring of areas with high population and sensitive properties.

Proper land use planning project should include reforestation, and application of structural and biological soil conservation strategies that can help to lessen the level of PLSH and their negative consequences. Landslide disaster risk preparedness and awareness creation for the communists living in high and very high PLSH should also be considered by the woreda Disaster Risk Management office.

\section{Acknowledgement}

The authors are grateful to Ambo University for the financial and operational supports to conduct this study. Ambo woreda community, Ambo woreda Agricultural office experts and Rural Developments of Ambo woreda also deserves appreciation for their kind cooperation in any requested information.

\section{References}

1. Abebe, B., Francesco, D., Giandomenico, F., Umera, M., Asrat, U., 2010. Landslides in the Ethiopian highlands and the Rift margins. Journal of African Earth Sciences 56, 131-138.

2. Ayalew, L \& Yamagishi, H., 2004. Slope movements in the Blue Nile basin, as seen from landscape evolution perspective. Geomorphology 57, 97-116.

3. Ayalew, L., 1999. The effect of seasonal rainfall on landslides in the highlands of Ethiopia. EngGeolEnv. 58, 9-19.

4. Ethiopian Central Statistical Agency (ECSA), 2010.The 2007 population and housing census of Ethiopia result for Oromia region. Addis Ababa.

5. FAO, 1974. Key to the FAO soil Units. UNESCO, Paris. www.fao.org/soils-portal.

6. Geertema, M. and Highland, L., 2011. Landslide: Human health effects. Fnccyclopedia of human health.

7. Geological Survey of Ethiopia(GSE), 1972. Geological map of Ethiopia. Ministry of mines, P.O.Box, addis Ababa, Ethiopia.

8. Girma, F., Raghuvanshi, T.K., Ayenew, T. and Hailemariam, T., 2015. Landslide Hazard zonation in Ada Berga district, Central Ethiopia- A GIS based statistical approach. Journal of Geomatics 9 (1) pp. 25-38.

9. Hamza, T., and Raghuvanshi T.K., 2016. GIS based landslide hazard evaluation and zonation. A case from Jeldu District, Central Ethiopia. Journal of King Saud University - Science 29, 151-165.

10. Karhoda, 2013. Landslides in densely populated country at the foot slopes Mount Elgon (Uganda): Characteristics and causal factors. Journal of Geomorphology 73,149-165.

11. Karsli, F., Yalcin, A., Atasoy, M. and Reis, S., 2008. Effects of land-use changes on landslides in a landslide prone area (Ardesen, Rize, NE Turkey). Environmental Monitoring and Assessment 15(1-4), 241-255.

12. Kifle, W., 2013. Review of the occurrences and influencing factors of landslide in the highlands of Ethiopia: with implications for infrastructural development. Momona Ethiopian journal of Science (MEJS) 5(1), 3-31.

13. Kifle, W., 2006. Characteristics of a large-scale landslide triggered by heavy rainfall in Tarmaber area, central highlands of Ethiopia. Geophysical Research Abstracts, 10: EGU2008-A-04506.

14. Mahler, C. F., Varanda, E., C. D. de Oliveira, L., 2012. Analytical Model of Landslide Risk Using GIS Open Journal of Geology, 2, 182-188. http://www.SciRP.org/journal/ojg

15. Mandler, B. 2017. Investigating Volcanic Landslide Hazards Modern tools improve risk assessment for volcanic landslides and debris flows. Americangeosciences.org/critical-issues.

16. Nakamura, S., Wakai, A., Umemura, J., Sugimoto, H., Takeshi, T. 2014. Earthquake-induced landslides: Distribution, motion and mechanisms. Soils and Foundations 54, 544-559.

17. Oztekin, B.; Topal, T., 2005. GIS-based detachment susceptibility analyses of a cut slope in Limestone, Ankara-Turkey. Environ. Geol. 49, 124-132.

18. Pourghasemi, H.R.; Moradi, H.R.; Aghda, S.M.F., 2013. Landslide susceptibility mapping by binary logistic regression, analytical hierarchy process, and statistical index models and assessment of their performances. Nat. Hazards, 69, 749-779.

19. Raghuvanshi, T.K., Ibrahim, J., Ayalew, D., 2014. Slope stability susceptibility evaluation parameter (SSEP) rating scheme - an approach for landslide hazard zonation. J. Afr. Earth Sci. 99, 595-612. 
20. Raghuvanshi, T.K., Negassa, L., Kala, P.M., 2015. GIS based grid overlay method versus modeling approach - a comparative study for Landslide Hazard Zonation (LHZ) in Meta Robi District of West Showa Zone in Ethiopia, Egypt. J. Remote Sens. Space Sci.18, 235-250.

21. Reichenbach, P., Busca, C. Mondini, A. C. Rossi, M. 2014. The Influence of Land Use Change on Landslide Susceptibility Zonation: The Briga Catchment Test Site (Messina, Italy). Environmental Management 54, 1372-1384. 